\title{
The Effect of Attitude of FKM UMJ Students on The Use of Paid Plastic Bags in 2021
}

\author{
${ }^{1}$ Allan Bahya Zahran, ${ }^{2}$ Atika Sari, ${ }^{3}$ Almairah Nurfauziah, ${ }^{4}$ Denita Nur Anisya, ${ }^{5}$ Munaya \\ Fauziah \\ ${ }^{1,2,3,4,5}$ Faculty of Public Health, Muhammadiyah University of Jakarta \\ K.H. Ahmad Dahlan St, Cirendeu, Ciputat, South Jakarta, Banten 15419 \\ Email: allanbz15@gmail.com
}

\begin{abstract}
Plastic, particularly plastic bags, is an object that cannot be separated from everyday life. Plastic bags can be used as a wrapper and to transport luggage or groceries, among other things. The use of plastic bags is out of control as a result of the practice of giving them out for free. As a result, better management is required to limit the usage of plastic bags, one of which is the establishment of a paid plastic bag policy. The goal of this study was to see how FKM UMJ students' opinions influenced their use of paid plastic bags in 2021. In June 2021, a qualitative investigation was done as part of this research. In-depth interviews and document reviews were used to acquire data. Purposive sampling was used to choose students from the FKM UMJ Class of 2019 as informants for this investigation. Based on the research that has been done, it is found that the influence of the attitude of FKM UMJ students towards the use of paid plastic bags is positive and supports government policies regarding this matter. So it's time for us to take wise steps in using single-use plastic bags.
\end{abstract}

Keywords: Plastic bag, Use, Plastic waste, Paid 


\section{INTRODUCTION}

Plastic is an object that cannot be separated from everyday life, especially plastic bags. One of the functions of plastic bags is as a wrapper and to carry luggage or groceries, whether in the form of food, drinks, clothing, or other household items. The cheap, practical, and compact nature of plastic bags make the use of plastic bags increasingly out of control.

The increase in the use of plastic bags is also related to the increase in the world population. This is reinforced by Lerdy and Anityasari (2011) in their research which states that in one year the world's population can use 500 million to 1 billion plastic bags, where each person uses 150 plastic bags each year. To make that much plastic, it takes 12 million barrels of oil and 14 million tree trunks that must be cut down as the basic raw materials for making it. (Astuti, 2016)

Quoted to BBC Indonesia (2016), around eight million tons of plastic waste circulates in the world's oceans every year. This fact is the result of research presented at the annual meeting of the American Association for the Advancement of Science (AAAS). According to the Minister of Maritime Affairs and Fisheries of the Republic of Indonesia, Susi Pudjiastuti, plastic waste that enters the sea can be broken down into small particles called microplastics with a size of 0.3-5 millimeters. Marine animals often consume microplastics here. (Utami et al., 2018)

Based on data obtained from the Indonesian Plastic Industry Association (NAPLES) and the Central Statistics Agency (BPS), there is a surprising fact that Indonesia is the second-largest plastic waste contributor in the world. Plastic waste in Indonesia reaches 64 million tons/year, of which 3.2 million tons is plastic waste that is dumped into the sea. According to the same source, 10 billion pieces of plastic bags are disposed of into the environment per year or as many as 85,000 tons of plastic bags. According to the Minister of Maritime Affairs and Fisheries of the Republic of Indonesia, Susi Pudjiastuti, plastic waste that enters the sea can be broken down into small particles called microplastics with a size of 0.3-5 millimeters. Marine animals often consume microplastics here. (Puspita, 2018 in Krisyanti, Vos and Priliantini, 2020)

Plastic bags are materials that are very easy to find in everyday life, their use can be found in almost every activity, for example, when buying something in big shops to small stalls, plastic bags are always used as a container to make it easier to carry something that is needed. has bought it. These plastic bags are obtained free of charge as a facility when buying something, not infrequently plastic bags are only used once and are immediately thrown away. Of course, habits like this are the problem with the accumulation of used plastic bag waste.

However, what needs to be underlined is that in terms of the production of plastic bags, what needs to be emphasized is human behavior that is not wise in using it. Many found cases of plastic bags being used only for one time, after which they were thrown away. Though the plastic bag can be reused for other purposes. This kind of attitude makes plastic bag waste scattered everywhere, and 
eventually becomes a pile of plastic. In other words, plastic bags or items made of plastic are human innovations that can meet the needs of life. Tools made of materials are generally durable, not easily damaged, can be used repeatedly, and are practical. In its development, these discoveries turned out to have a negative impact that could be considered detrimental to humans themselves. Plastic waste includes waste that is difficult to decompose by natural processes, so it takes hundreds of years to destroy it. (Acrom, 2019)

For this reason, it is important to improve management to reduce the use of plastic bags, one of which is the implementation of a paid plastic bag policy. The paid plastic bag policy is one of the programs that aim to reduce waste generation, especially plastic waste. In Indonesia, the new plastic bag policy was implemented in February 2016 to coincide with the National Waste Care Day. (Krisyanti, Vos, and Priliantini, 2020)With the habit of giving plastic bags for free, the use of plastic bags is getting out of control. Efforts to reduce the use of plastic bags can indirectly inhibit global warming and maintain environmental sustainability. (Astuti, 2016)

This study aims to determine the effect of the attitudes of FKM UMJ students on the use of paid plastic bags in 2021. The benefits of knowing the attitudes of FKM UMJ students towards the use of plastic bags, knowing the negative and positive impacts of using plastic bags, and knowing how effective the application of paid plastic bags is. This research was conducted from June 18, 2021 - June 21, 2021. Where the respondents were students of the University of Muhammadiyah Jakarta, Faculty of Public Health, batch 2019.

\section{METHODS}

This research was conducted with a qualitative study conducted in June 2021. Data collection was carried out by in-depth interviews and document review. Informants from this study were students of FKM UMJ Class of 2019 who were selected by purposive sampling.

\section{RESULTS}

DISCUSSION

Table 1. Interview Matrix

\begin{tabular}{|c|c|c|c|c|c|}
\hline TOPICS & MEANING UNITS & CODE & SUBCATEGORY & CATEGORY & THEME \\
\hline $\begin{array}{l}\text { 1. What is your } \\
\text { attitude when } \\
\text { you don't } \\
\text { bring plastic } \\
\text { bags when } \\
\text { shopping and } \\
\text { what do you } \\
\text { think about } \\
\text { paid plastic } \\
\text { bags? }\end{array}$ & $\begin{array}{l}\text { In my opinion, when } \\
\text { shopping and } \\
\text { forgetting to bring a } \\
\text { plastic bag, it is better } \\
\text { to take the initiative } \\
\text { to carry a spare eco- } \\
\text { friendly bag/cloth bag } \\
\text { on a motorbike or in } \\
\text { a bag, or a hanger } \\
\text { containing a cloth } \\
\text { bag to make it easy to } \\
\text { carry everywhere. In } \\
\text { my opinion, about }\end{array}$ & $\begin{array}{l}\text { Take the } \\
\text { initiative to } \\
\text { carry a spare } \\
\text { eco-friendly } \\
\text { bag and hang } \\
\text { the bag on the } \\
\text { motorbike so } \\
\text { that it is easy } \\
\text { to carry } \\
\text { anywhere. }\end{array}$ & $\begin{array}{l}\text { The initiative hung } \\
\text { on the motor }\end{array}$ & $\begin{array}{l}\text { Have an idea } \\
\text { or idea }\end{array}$ & $\begin{array}{l}\text { The } \\
\text { existence of } \\
\text { ideas, } \\
\text { enthusiasm, } \\
\text { desires, and } \\
\text { policies } \\
\text { from the } \\
\text { government. }\end{array}$ \\
\hline
\end{tabular}




\begin{tabular}{|c|c|c|c|c|}
\hline TOPICS & MEANING UNITS & CODE & SUBCATEGORY & CATEGORY \\
\hline & $\begin{array}{l}\text { paid plastic, this has } \\
\text { become public } \\
\text { awareness that there } \\
\text { has been an appeal } \\
\text { not to use plastic bags } \\
\text { and it is preferable to } \\
\text { use environmentally } \\
\text { friendly bags or cloth } \\
\text { bags that can be used } \\
\text { many times. }\end{array}$ & & & \\
\hline & $\begin{array}{l}\text { My attitude is } \\
\text { normal, but I'm a bit } \\
\text { lazy to fill the house. }\end{array}$ & $\begin{array}{l}\text { Be normal but } \\
\text { lazy with the } \\
\text { plastic waste }\end{array}$ & $\begin{array}{l}\text { It's normal and lazy } \\
\text { to have plastic } \\
\text { waste piling up. }\end{array}$ & $\begin{array}{lr}\text { It } & \text { takes } \\
\text { passion } & \text { and } \\
\text { will } & \text { from }\end{array}$ \\
\hline & $\begin{array}{l}\text { Opinions about paid } \\
\text { plastic bags are good, } \\
\text { so people who don't } \\
\text { carry a bag/tote bag } \\
\text { can think about the } \\
\text { consequences, it's } \\
\text { worth } 200 \text { silver. }\end{array}$ & $\begin{array}{l}\text { up. } \\
\text { His opinion is } \\
\text { that the } \\
\text { existence of } \\
\text { paid plastic } \\
\text { bags is good } \\
\text { because it will } \\
\text { make buyers } \\
\text { think again to } \\
\text { buy. }\end{array}$ & $\begin{array}{l}\text { Good and think } \\
\text { again. }\end{array}$ & $\begin{array}{l}\text { have thoughts } \\
\text { for the future }\end{array}$ \\
\hline & $\begin{array}{l}\text { My attitude is that in } \\
\text { stores there are also } \\
\text { other options to buy a } \\
\text { tote bag or paper bag, } \\
\text { it's better to buy a } \\
\text { tote bag or paper bag } \\
\text { instead of using a } \\
\text { plastic bag because if } \\
\text { you buy a tote bag, } \\
\text { you can use it long } \\
\text { term, while if it's } \\
\text { plastic it will be } \\
\text { damaged and even if } \\
\text { the item is still } \\
\text { available, it, why } \\
\text { not? For example, } \\
\text { dance on a motorbike } \\
\text { or in a car instead of } \\
\text { using plastic. }\end{array}$ & $\begin{array}{l}\text { It is better to } \\
\text { buy a tote bag } \\
\text { or paper bag } \\
\text { provided at the } \\
\text { store because } \\
\text { it can be used } \\
\text { long-term } \\
\text { rather than } \\
\text { having to use } \\
\text { plastic. }\end{array}$ & $\begin{array}{ll}\text { Tote bag, paper } \\
\text { bag, long term, } \\
\text { plastic }\end{array}$ & $\begin{array}{l}\text { There is a } \\
\text { policy and } \\
\text { firmness }\end{array}$ \\
\hline
\end{tabular}

My opinion is positive if for example plastic bags are paid for, people will be lazy to buy plastic bags because it's useless to spend money to buy plastic bags, it's better to bring your shopping place so it's more efficient, so it saves
Positive

because if for example the plastic bag is paid for, surely people will be lazy to buy plastic bags. 


\begin{tabular}{|c|c|c|c|c|c|}
\hline \multirow[t]{2}{*}{ TOPICS } & \multirow[b]{2}{*}{$\begin{array}{l}\text { MEANING UNITS } \\
\text { costs, then let's say } \\
\text { plastic bags are made } \\
\text { for a fee he can } \\
\text { reduce the amount of } \\
\text { plastic in Indonesia } \\
\text { too }\end{array}$} & \multirow[t]{2}{*}{ CODE } & \multirow[t]{2}{*}{ SUBCATEGORY } & \multirow[t]{2}{*}{ CATEGORY } & \multirow[t]{2}{*}{ THEME } \\
\hline & & & & & \\
\hline & $\begin{array}{l}\text { For example, if I'm } \\
\text { shopping at Indomart, } \\
\text { if I don't bring a } \\
\text { plastic bag, it's } \\
\text { normal. But now, } \\
\text { when you go to the } \\
\text { mall, you can't bring } \\
\text { a plastic bag, so } \\
\text { sometimes you feel } \\
\text { worried and lazy to } \\
\text { handle it. }\end{array}$ & $\begin{array}{l}\text { Lazy when } \\
\text { shopping at } \\
\text { the } \\
\text { supermarket, } \\
\text { but worried } \\
\text { when } \\
\text { shopping at } \\
\text { the mall if you } \\
\text { don't bring a } \\
\text { shopping bag. }\end{array}$ & 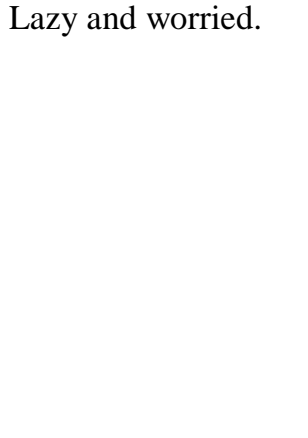 & Difficulty & \\
\hline & $\begin{array}{l}\text { If it's a paid plastic } \\
\text { bag, it doesn't matter, } \\
\text { as long as the plastic } \\
\text { bag is still under } 500 \\
\text { silver. It's just that if } \\
\text { we are told to pay } \\
\text { directly above } 1000- \\
2000 \text {, I don't think it's } \\
\text { right. }\end{array}$ & $\begin{array}{l}\text { It doesn't } \\
\text { matter if the } \\
\text { price of a } \\
\text { plastic bag is } \\
\text { under } 500 \\
\text { silver. }\end{array}$ & Does not matter. & & \\
\hline $\begin{array}{l}\text { 2. How do you } \\
\text { respond to } \\
\text { supermarkets } \\
\text { that do not } \\
\text { provide free } \\
\text { plastic bags } \\
\text { and sell them } \\
\text { for Rp. } 200 \\
\text { per sheet? }\end{array}$ & $\begin{array}{l}\text { I think the attitude of } \\
\text { the sellers in the } \\
\text { market is good } \\
\text { because they include } \\
\text { preventing the use of } \\
\text { plastic for now who } \\
\text { are facing a reduction } \\
\text { in the use of plastic } \\
\text { but if the price of } \\
\text { plastic bags is Rp. } \\
200 \text { per sheet sold by } \\
\text { the seller, but the } \\
\text { buyer can reach it } \\
\text { easily. }\end{array}$ & $\begin{array}{lr}\text { A } & \text { good } \\
\text { attitude } & \text { from } \\
\text { the seller } & \text { but } \\
\text { the buyer } & \text { still } \\
\text { reaches } & \text { out } \\
\text { with } & \text { a } \\
\text { payment } & \text { of } \\
\text { Rp. 200 per } \\
\text { sheet. }\end{array}$ & $\begin{array}{l}\text { Good attitude and } \\
\text { affordable price. }\end{array}$ & agree & $\begin{array}{l}\text { Health } \\
\text { promotion } \\
\text { activities } \\
\text { and } \\
\text { prohibitions. }\end{array}$ \\
\hline & $\begin{array}{l}\text { It's good, it can make } \\
\text { people aware too. For } \\
\text { example, someone } \\
\text { who buys up to } 5 \\
\text { plastic bags, } \\
\text { multiplies } 200 \text { to } \\
\begin{array}{l}1000.1000 \text { can be } \\
\text { used for other } \\
\text { purchases. }\end{array}\end{array}$ & $\begin{array}{l}\text { Good because } \\
\text { it can make } \\
\text { people aware, } \\
\text { and can be } \\
\text { more efficient } \\
\text { in the use of } \\
\text { money. }\end{array}$ & $\begin{array}{l}\text { Make people aware } \\
\text { and efficient. }\end{array}$ & $\begin{array}{l}\text { Educate } \\
\text { public }\end{array}$ & \\
\hline & $\begin{array}{l}\text { Ok, that means he is } \\
\text { contributing to } \\
\text { reducing the use of } \\
\text { plastic bags } \\
\text { themselves. But it }\end{array}$ & $\begin{array}{l}\text { Good, because } \\
\text { these } \\
\text { supermarkets } \\
\text { contribute to } \\
\text { reducing the }\end{array}$ & $\begin{array}{l}\text { Reduce the use of } \\
\text { plastic bags }\end{array}$ & $\begin{array}{l}\text { Ban on the use } \\
\text { of plastic bags }\end{array}$ & \\
\hline
\end{tabular}




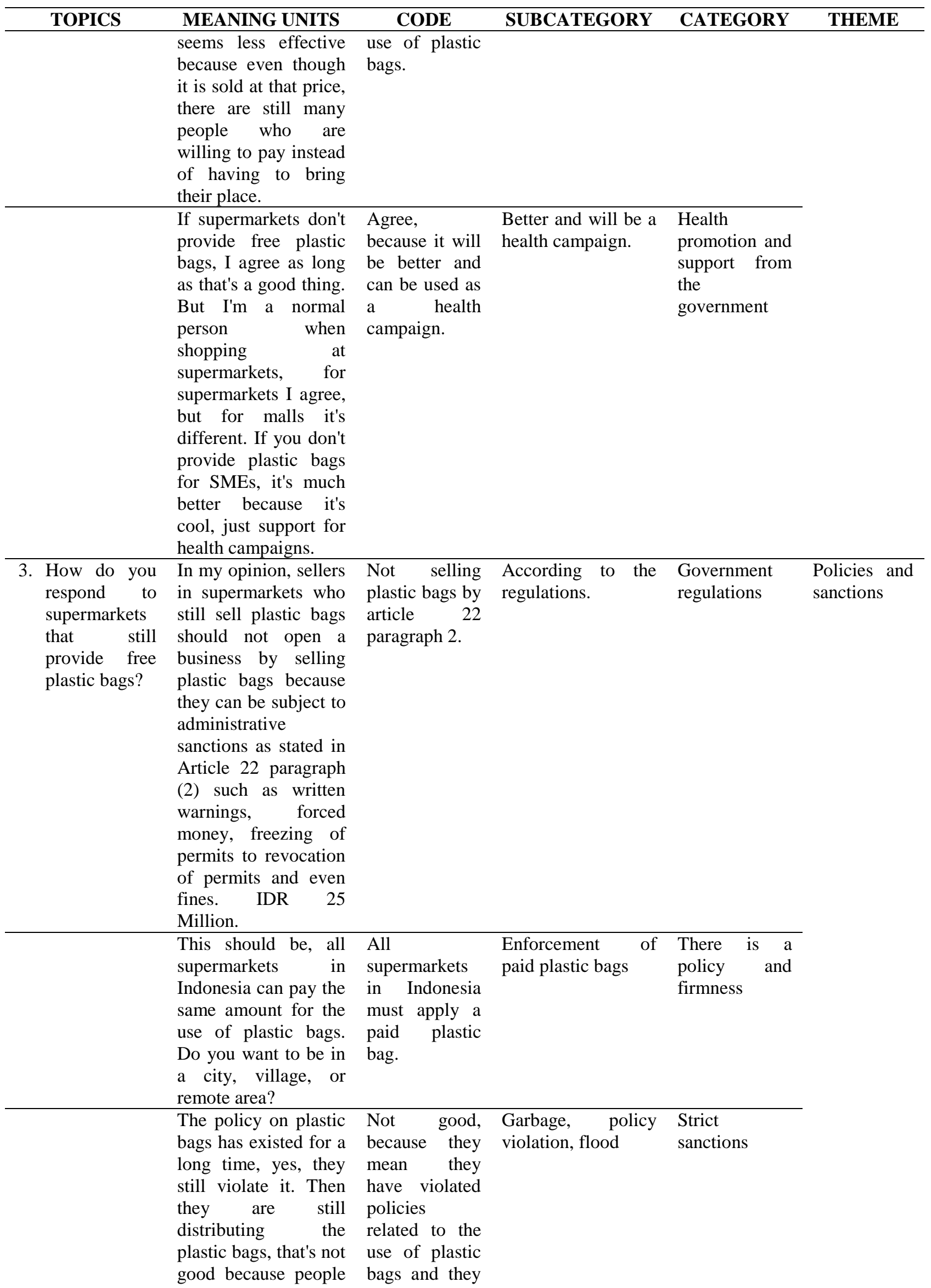




\begin{tabular}{|c|c|c|c|c|c|}
\hline TOPICS & MEANING UNITS & CODE & SUBCATEGORY & CATEGORY & THEME \\
\hline & $\begin{array}{l}\text { will shop there to get } \\
\text { free plastic bags, then } \\
\text { they will be thrown } \\
\text { away carelessly and } \\
\text { that's what causes } \\
\text { flooding, so they } \\
\text { contribute to flooding } \\
\text { everywhere. }\end{array}$ & $\begin{array}{l}\text { contribute to } \\
\text { plastic waste } \\
\text { that is thrown } \\
\text { carelessly } \\
\text { where the } \\
\text { garbage can } \\
\text { potentially } \\
\text { cause } \\
\text { flooding. }\end{array}$ & & & \\
\hline & $\begin{array}{l}\text { Lack of and disagree, } \\
\text { it must be from the } \\
\text { consumers } \\
\text { themselves who are } \\
\text { aware of bringing } \\
\text { their plastic bags. }\end{array}$ & $\begin{array}{l}\text { Disagree, } \\
\text { consumers } \\
\text { should be } \\
\text { aware to bring } \\
\text { their plastic } \\
\text { bags. }\end{array}$ & Disagree. & & \\
\hline \multirow[t]{4}{*}{$\begin{array}{l}\text { 4. In your } \\
\text { opinion, what } \\
\text { are the } \\
\text { advantages } \\
\text { and } \\
\text { disadvantages } \\
\text { of using } \\
\text { plastic bags? }\end{array}$} & $\begin{array}{l}\text { In my opinion, the } \\
\text { advantages and } \\
\text { benefits of using } \\
\text { plastic bags are that } \\
\text { they are very cheap, } \\
\text { practical to use in } \\
\text { daily activities, } \\
\text { flexible/flexible, not } \\
\text { rusty, lightweight and } \\
\text { can be made into } \\
\text { sheets. }\end{array}$ & $\begin{array}{l}\text { Plastic bags } \\
\text { are very } \\
\text { cheap, } \\
\text { practically } \\
\text { used in daily } \\
\text { activities. }\end{array}$ & $\begin{array}{l}\text { Cheap } \\
\text { practical. }\end{array}$ & $\begin{array}{l}\text { Make it easy } \\
\text { for consumers }\end{array}$ & Easy \\
\hline & $\begin{array}{l}\text { The advantages are } \\
\text { the same as the } \\
\text { advantages of being } \\
\text { practical, everywhere } \\
\text { there are plastic bags. } \\
\text { The downside is that } \\
\text { it's hard to explain, it } \\
\text { takes a long time. }\end{array}$ & $\begin{array}{l}\text { More practical } \\
\text { because it is } \\
\text { everywhere, } \\
\text { and has } \\
\text { shortcomings } \\
\text { that are } \\
\text { difficult to } \\
\text { describe. }\end{array}$ & $\begin{array}{l}\text { Practical and } \\
\text { difficult to parse. }\end{array}$ & $\begin{array}{l}\text { Difficult } \\
\text { recycle }\end{array}$ & \\
\hline & $\begin{array}{l}\text { There is, for example, } \\
\text { that plastic can be } \\
\text { recycled into more } \\
\text { useful things, for } \\
\text { example, made into } \\
\text { bags made of woven } \\
\text { plastic bags. }\end{array}$ & $\begin{array}{l}\text { The plastic } \\
\text { can be } \\
\text { recycled into } \\
\text { something } \\
\text { more useful. }\end{array}$ & Recycle, benefit & & \\
\hline & $\begin{array}{l}\text { The advantages are } \\
\text { clear, efficient, our } \\
\text { time is faster, we } \\
\text { don't need to look for } \\
\text { non-plastic bags, it's } \\
\text { not complicated, it's } \\
\text { fast too. We don't } \\
\text { donate trash, donate } \\
\text { pollution, donate all } \\
\text { kinds of negative } \\
\text { things. }\end{array}$ & $\begin{array}{l}\text { Efficient, } \\
\text { easy, fast. }\end{array}$ & Efficient, easy, fast. & & \\
\hline $\begin{array}{l}\text { 5. What is your } \\
\text { solution } \\
\text { regarding the } \\
\text { excessive use } \\
\text { of plastic bags }\end{array}$ & $\begin{array}{l}\text { In my opinion, the } \\
\text { solution to the } \\
\text { excessive use of } \\
\text { plastic bags should be } \\
\text { replaced }\end{array}$ & $\begin{array}{l}\text { Using } \\
\text { environmental } \\
\text { ly friendly } \\
\text { bags made of } \\
\text { cloth to invite }\end{array}$ & $\begin{array}{l}\text { Eco-friendly plastic } \\
\text { bags, made of cloth, } \\
\text { use plastic bags } \\
\text { wisely, reduce } \\
\text { negative impacts, }\end{array}$ & $\begin{array}{l}\text { Self- } \\
\text { awareness }\end{array}$ & $\begin{array}{l}\text { Reuse/recycl } \\
\text { e, bring your } \\
\text { equipment } \\
\text { and replace } \\
\text { plastic raw }\end{array}$ \\
\hline
\end{tabular}




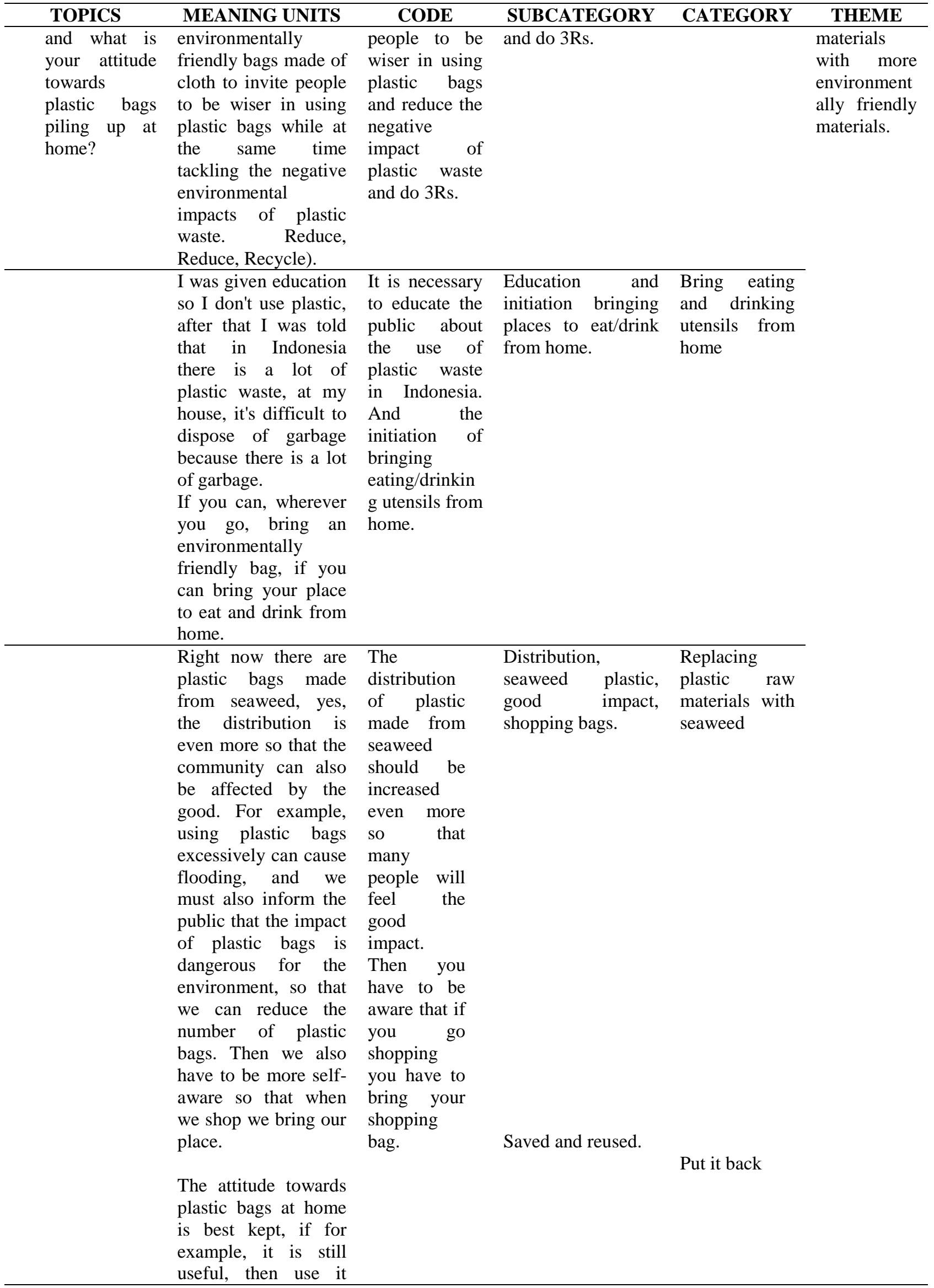




\begin{tabular}{|c|c|c|c|c|c|}
\hline TOPICS & MEANING UNITS & CODE & SUBCATEGORY & CATEGORY & THEME \\
\hline & $\begin{array}{l}\text { again to put } \\
\text { something else. }\end{array}$ & & & & \\
\hline & & $\begin{array}{l}\text { The attitude } \\
\text { towards } \\
\text { plastic bags at } \\
\text { home is best } \\
\text { kept, if they } \\
\text { are still useful, } \\
\text { of course, they } \\
\text { are reused to } \\
\text { put something } \\
\text { else. }\end{array}$ & & & \\
\hline & $\begin{array}{l}\text { First of all, we must } \\
\text { have the self- } \\
\text { awareness to hold } \\
\text { back, for example, if } \\
\text { we shop, we hold } \\
\text { ourselves back so we } \\
\text { don't touch this } \\
\text { plastic bag. As much } \\
\text { as possible, before } \\
\text { shopping, we intend } \\
\text { ourselves if we don't } \\
\text { want to donate too } \\
\text { much plastic. That's } \\
\text { why we make it like } \\
\text { an environmentally } \\
\text { friendly bag. Second, } \\
\text { a good solution is that } \\
\text { we make fun of it on }\end{array}$ & $\begin{array}{l}\text { Self- } \\
\text { awareness, } \\
\text { intend not to } \\
\text { use excessive } \\
\text { plastic bags, } \\
\text { make eco- } \\
\text { friendly } \\
\text { shopping } \\
\text { bags/plastic } \\
\text { bags, and } \\
\text { campaign } \\
\text { through social } \\
\text { media. }\end{array}$ & $\begin{array}{l}\text { Self-awareness, } \\
\text { intention, making } \\
\text { shopping bags, } \\
\text { campaigns. }\end{array}$ & 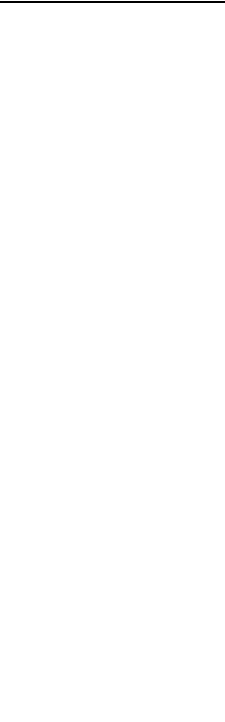 & \\
\hline & $\begin{array}{l}\text { Instagram like a } \\
\text { campaign. }\end{array}$ & & $\begin{array}{l}\text { Put it in the waste } \\
\text { bank and make } \\
\text { decorations. }\end{array}$ & $\begin{array}{l}\text { Make crafts or } \\
\text { collect them to } \\
\text { the manager }\end{array}$ & \\
\hline & $\begin{array}{l}\text { The first is that there } \\
\text { are lots of plastic } \\
\text { bags, I'm going to the } \\
\text { garbage bank. I } \\
\text { collect it for up to a } \\
\text { month, when it's been } \\
\text { a month I change it to } \\
\text { the waste bank, the } \\
\text { waste that is } \\
\text { exchanged } \\
\text { money. } \\
\text { Second, sometimes I } \\
\text { make decorations or } \\
\text { paintings when I'm } \\
\text { having fun and I don't } \\
\text { have anything to do } \\
\text { at home, my hobbies } \\
\text { are also drawing and } \\
\text { painting. I often make } \\
\text { up the pictures in a } \\
\text { plastic bag, so in the } \\
\text { end, I throw it away } \\
\text { or put it in a garbage }\end{array}$ & $\begin{array}{l}\text { Put it in the } \\
\text { waste bank } \\
\text { and paint it for } \\
\text { decoration. }\end{array}$ & & & \\
\hline
\end{tabular}




\section{TOPICS} MEANING UNITS CODE SUBCATEGORY

bank.

The paid plastic bag policy is a concrete effort by the government to reduce waste generation from waste-producing sources. The pricing policy in this policy is intended to make people think again about using new plastic bags from their shops. This will indirectly reduce the amount of waste that will be sent to the community/consumers. One alternative to reduce the use of plastic bags is to bring your shopping bags that are not disposable.

In the interview, we asked the informants how they behaved when they did not bring their shopping bags when shopping, some informants said that they got around this by buying reusable bags such as tote bags or paper bags provided at the supermarket. The following is the statement of one respondent:

"It's better to buy a tote bag or paper bag provided at the store because it can be used for a long time rather than having to use plastic."

Public awareness is needed in using single-use plastic bags when shopping. In the paid plastic policy, the recommended price is Rp. 200. Supermarkets charge consumers a price for each new plastic bag they use. Based on the results of the interview, the informants welcomed it positively, because they thought it was good to do it by existing policies. However, because the price of plastic bags is affordable, it allows consumers to continue to buy them and is considered less effective.

"I think the attitude of the supermarkets is good because they include preventing the use of plastic for now, which is currently facing a reduction in the use of plastic, but if the price of plastic bags is Rp. 200 per sheet sold by supermarkets, still buyers can reach them easily."

Based on the informant's narrative, the researcher concluded that the application of paid plastic bags was considered less effective because plastic bags were sold for Rp. 200 can still be reached by the community. Although there are provisions regarding the use of paid plastic bags, there are still some supermarkets that provide them for free. Then we asked the opinion of the informants regarding this matter. From the interview results, it was found that all informants did not agree with the supermarket policy to provide plastic bags for free, because it could contribute to the amount of plastic waste.

The results of our interviews with informants about the advantages and benefits of using plastic bags, some of the informants answered that it is more practical and accessible in everyday life and if recycled plastic bags can be more useful. One of the programs to handle solid waste problems is the principle of Reduce and Reuse. The more we use materials, the more waste is generated. Reuse is Re-use (reuse) as much as possible, choose items that can be reused. Avoid using items that are disposable (one-time use, throw away). This can extend the time of using goods before they become waste (Hadiwiyoto, 1983 in Nur Jamilah 2018). 
"The advantages are the same as the advantages, so it's practical, everywhere there are plastic bags. The downside is that it's hard to explain, it takes a long time. There are, for example, that plastic can be recycled into more useful things, for example, made into bags made from plastic bags." 
Table 2. Summary of the analysis: code, sub-categories, categories, and themes

\begin{tabular}{|c|c|c|c|c|c|c|c|c|c|c|}
\hline \multirow{3}{*}{$\begin{array}{c}\text { Theme } \\
\text { Category } \\
\text { Sub-category }\end{array}$} & \multicolumn{10}{|c|}{ The existence of ideas, enthusiasm, desires, and policies from the government } \\
\hline & \multicolumn{2}{|c|}{ Have an idea or idea } & \multicolumn{2}{|c|}{ Agree } & \multicolumn{2}{|c|}{ Government regulations } & \multicolumn{2}{|c|}{$\begin{array}{c}\text { Make it easy for } \\
\text { consumers }\end{array}$} & \multicolumn{2}{|c|}{ Self-awareness } \\
\hline & $\begin{array}{l}\text { The initiative } \\
\text { hung on the } \\
\text { motor }\end{array}$ & $\begin{array}{c}\text { Does not } \\
\text { matter }\end{array}$ & $\begin{array}{c}\text { Good attitude } \\
\text { and affordable } \\
\text { price. }\end{array}$ & $\begin{array}{l}\text { Better and } \\
\text { will be a } \\
\text { health } \\
\text { campaign. }\end{array}$ & $\begin{array}{l}\text { According to } \\
\text { the } \\
\text { regulations. }\end{array}$ & Disagree & $\begin{array}{l}\text { Cheap and } \\
\text { practical. }\end{array}$ & $\begin{array}{l}\text { Efficient, } \\
\text { easy, fast. }\end{array}$ & $\begin{array}{c}\text { Eco-friendly } \\
\text { plastic bags, } \\
\text { made of cloth, } \\
\text { use plastic } \\
\text { bags wisely, } \\
\text { reduce } \\
\text { negative } \\
\text { impacts, and } \\
\text { do 3Rs. }\end{array}$ & $\begin{array}{c}\text { Put it in the } \\
\text { waste bank and } \\
\text { make } \\
\text { decorations. }\end{array}$ \\
\hline Code & $\begin{array}{l}\text { - Take the } \\
\text { initiative } \\
\text { to carry a } \\
\text { spare } \\
\text { eco- } \\
\text { friendly } \\
\text { bag and } \\
\text { hang the } \\
\text { bag on } \\
\text { the } \\
\text { motorbik } \\
\text { e so that } \\
\text { it is easy } \\
\text { to carry } \\
\text { anywhere } \\
\text {. } \\
\text { Be } \\
\text { normal } \\
\text { but lazy } \\
\text { with the } \\
\text { plastic } \\
\text { waste that }\end{array}$ & 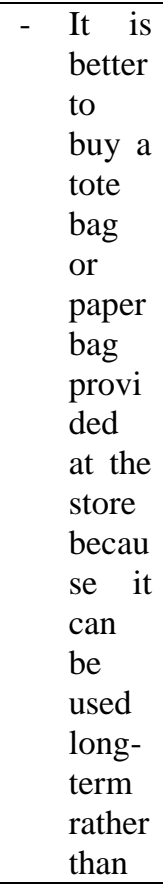 & $\begin{array}{l}\text { - A good } \\
\text { attitude from } \\
\text { the seller but } \\
\text { the buyer } \\
\text { still reaches } \\
\text { out with a } \\
\text { payment of } \\
\text { Rp. } 200 \text { per } \\
\text { sheet. } \\
\text { - Good } \\
\text { because it } \\
\text { can make } \\
\text { people } \\
\text { aware, and } \\
\text { can be more } \\
\text { efficient in } \\
\text { the use of } \\
\text { money. }\end{array}$ & $\begin{array}{l}\text { - } \begin{array}{l}\text { Good, } \\
\text { because }\end{array} \\
\text { these } \\
\text { superma } \\
\text { rkets } \\
\text { contribut } \\
\text { e to } \\
\text { reducing } \\
\text { the use } \\
\text { of plastic } \\
\text { bags. } \\
\text { Agree, } \\
\text { because } \\
\text { it will be } \\
\text { better } \\
\text { and can } \\
\text { be used } \\
\text { as a } \\
\text { health } \\
\text { campaig } \\
\text { n. }\end{array}$ & $\begin{array}{ll}\text { - } & \text { Not } \\
\text { selling } \\
\text { plastic } \\
\text { bags by } \\
\text { article } \\
22 \\
\text { paragrap } \\
\text { h } 2 . \\
\text { - All } \\
\text { superma } \\
\text { rkets in } \\
\text { Indonesi } \\
\text { a must } \\
\text { apply a } \\
\text { paid } \\
\text { plastic } \\
\text { bag. }\end{array}$ & $\begin{array}{l}\text { Not } \\
\text { good, } \\
\text { because } \\
\text { they } \\
\text { mean } \\
\text { they } \\
\text { have } \\
\text { violated } \\
\text { policies } \\
\text { related } \\
\text { to the } \\
\text { use of } \\
\text { plastic } \\
\text { bags and } \\
\text { they } \\
\text { contribut } \\
\text { e to } \\
\text { plastic } \\
\text { waste } \\
\text { that is } \\
\text { thrown } \\
\text { carelessl }\end{array}$ & $\begin{array}{l}\text { - Plastic } \\
\text { bags are } \\
\text { very } \\
\text { cheap, } \\
\text { practically } \\
\text { used in } \\
\text { daily } \\
\text { activities. } \\
\text { - More } \\
\text { practical } \\
\text { because it } \\
\text { is } \\
\text { everywher } \\
\text { e, and has } \\
\text { shortcomi } \\
\text { ngs that } \\
\text { are } \\
\text { difficult to } \\
\text { describe. }\end{array}$ & $\begin{array}{l}\text { - The } \\
\text { plastic } \\
\text { can be } \\
\text { recycled } \\
\text { into } \\
\text { somethin } \\
\text { g more } \\
\text { useful. } \\
\text { - Efficient } \\
\text {, easy, } \\
\text { fast }\end{array}$ & $\begin{array}{l}\text { - Using } \\
\text { environment } \\
\text { ally friendly } \\
\text { bags made } \\
\text { of cloth to } \\
\text { invite } \\
\text { people to be } \\
\text { wiser in } \\
\text { using plastic } \\
\text { bags and } \\
\text { reduce the } \\
\text { negative } \\
\text { impact of } \\
\text { plastic } \\
\text { waste and } \\
\text { do 3Rs. } \\
\text { - It is } \\
\text { necessary to } \\
\text { educate the } \\
\text { public about } \\
\text { the use of } \\
\text { plastic }\end{array}$ & $\begin{array}{l}\text { - The } \\
\text { distribution } \\
\text { of plastic } \\
\text { made from } \\
\text { seaweed } \\
\text { should be } \\
\text { increased } \\
\text { even more so } \\
\text { that many } \\
\text { people will } \\
\text { feel the good } \\
\text { impact. Then } \\
\text { you have to } \\
\text { be aware that } \\
\text { if you go } \\
\text { shopping, } \\
\text { you have to } \\
\text { bring your } \\
\text { shopping } \\
\text { bag } \\
\text { Self- } \\
\text { awareness, }\end{array}$ \\
\hline
\end{tabular}




\begin{tabular}{|c|c|c|c|c|c|c|c|}
\hline \multirow{2}{*}{$\begin{array}{c}\text { Theme } \\
\text { Category }\end{array}$} & \multicolumn{7}{|c|}{ The existence of ideas, enthusiasm, desires, and policies from the government } \\
\hline & Have an ide & dea & Agree & Government regulations & $\begin{array}{c}\text { Make it easy for } \\
\text { consumers }\end{array}$ & Self-av & areness \\
\hline & $\begin{array}{l}\text { has piled } \\
\text { up. } \\
\text { - His } \\
\text { opinion is } \\
\text { that the } \\
\text { existence } \\
\text { of paid } \\
\text { plastic } \\
\text { bags is } \\
\text { good } \\
\text { because it } \\
\text { will make } \\
\text { buyers } \\
\text { think } \\
\text { again to } \\
\text { buy. }\end{array}$ & $\begin{array}{l}\text { havin } \\
\text { g to } \\
\text { use } \\
\text { plasti } \\
\text { c. } \\
\text { Positi } \\
\text { ve, } \\
\text { beca } \\
\text { use if } \\
\text { for } \\
\text { exam } \\
\text { ple } \\
\text { the } \\
\text { plasti } \\
\text { c bag } \\
\text { is } \\
\text { paid } \\
\text { for, } \\
\text { surel } \\
\text { y } \\
\text { peopl } \\
\text { e will } \\
\text { be } \\
\text { lazy } \\
\text { to } \\
\text { buy } \\
\text { plasti } \\
\text { c } \\
\text { bags }\end{array}$ & & $\begin{array}{l}\text { y where } \\
\text { the } \\
\text { garbage } \\
\text { can } \\
\text { potential } \\
\text { ly cause } \\
\text { flooding. } \\
\text { - Disagree } \\
\text { consume } \\
\text { rs should } \\
\text { be aware } \\
\text { to bring } \\
\text { their } \\
\text { plastic } \\
\text { bags. }\end{array}$ & & $\begin{array}{l}\text { waste in } \\
\text { Indonesia. } \\
\text { And the } \\
\text { initiation of } \\
\text { bringing } \\
\text { eating/drinki } \\
\text { ng utensils } \\
\text { from home. }\end{array}$ & $\begin{array}{l}\text { intend not to } \\
\text { use excessive } \\
\text { plastic bags, } \\
\text { make eco- } \\
\text { friendly } \\
\text { shopping } \\
\text { bags/plastic } \\
\text { bags, and } \\
\text { campaign } \\
\text { through social } \\
\text { media. } \\
\text { - Put it in the } \\
\text { waste bank } \\
\text { and paint it } \\
\text { for } \\
\text { decoration. }\end{array}$ \\
\hline
\end{tabular}


E-ISSN: 2808-5361

http://e-journal.fkmumj.ac.id/
Proceeding The First

Muhammadiyah Internasional-

Public Health and Medicine

Conference

The results of our interviews with informants what solutions did the informants do if they used plastic bags and attitudes towards plastic bags if they piled up at home, some of the informants answered that they invited people to be wiser in using plastic bags and reduce the negative impact of plastic waste and do 3Rs and use environmentally friendly bags.

"I think the attitude for plastic bags that accumulate at home should be done 3R (Reduce, Reduce, Recycle)."

"First of all, I have a lot of plastic bags. I collect it for up to a month, when it's been a month I change it to the waste bank, the waste that is exchanged into money."

The results of our interviews with informants what solutions did the informants do if they used plastic bags and attitudes towards plastic bags if they piled up at home, some of the informants answered that they invited people to be wiser in using plastic bags and reduce the negative impact of plastic waste and do 3Rs and use environmentally friendly bags.

\section{CONCLUSIONS AND SUGGESTIONS}

Reduction of the use of single-use plastic bags must continue to be carried out, as an effort to reduce the pile of plastic waste which can ultimately hurt the environment. In this regard, the government through the Ministry of Environment and Forestry issued a Circular regarding the application of the price and mechanism for paid plastic bags at modern retailers number SE06/PSLB3-PS/2015 and number SE-1230/PSLB3-PS/2016.

Based on the research that has been done, it is found that the attitude of students towards the paid plastic bag policy is positive and supports the policy. One respondent prefers to buy a shopping bag/tote bag provided at the modern retailer because it can be used for a long time. Then other respondents took a 3R (Reuse, Reduce, Recycle) attitude towards the plastic waste that had started to accumulate in their homes.

The problem of plastic waste is not only the responsibility of one party but the responsibility of all of us. The many negative impacts caused by the accumulation of plastic waste in the environment should be enough to open our eyes and make us realize that all parties including the government, related sectors, and the community take an important role in fixing this plastic waste problem. So now is the time for us to take wise steps in using single-use plastic bags.

\section{REFERENCES}

Chandra, B. (2006) Introduction to Environmental Health.

Astuti, AD (2016) 'Implementation of Paid Plastic Bags as an Effort to Reduce the Use of Plastic Bags', XII(1), pp. 32-40.

Chandra, B. (2006) Introduction to Environmental Health.

Directorate General of PPKL-KLKH (2018) Control of Industrial Plastic Waste. 
Economics, F., Management, J. and Ratulangi, US (2019) 'Factors of Employee Loyalty in the Regional Education Office of North Sulawesi Province', EMBA Journal: Journal of Economic Research, Management, Business and Accounting, 7(1), pp. 671-680. doi:10.35794/emba.v7i1.22478.

Fatimura, M. (2020) 'Performance Evaluation of Non-Catalyst Pyrolysis Reactor in Converting Plastic Waste into Fuel Oil', Scientific Journal of Chemical Engineering, 4, pp. 1-7.

Fay, DL (1967) 'RELATED ATTITUDE OF AUFA ROYHAN STIKES EMPLOYEES WITH THE USE OF PLASTIC BAG', Angewandte Chemie International Edition, 6(11), 951-952., 8(1), pp. 26-30.

Guslaida, M., Naria, E. and Santi, DN (2014) 'Keywords: Characteristics, Knowledge, Attitudes, The usage of plastic bags.'

Jamilah, NUR (2018) Behavioral Analysis of State Elementary School Students About the Use and Dangers of Crackle Plastic Bags in Medan Johor District, Medan City in 2018. North Sumatra.

KBBI Online(2016). Available at: https://kbbi.kemdikbud.go.id/entri/gunakan (Accessed: 14 July 2021).

Ministry of Environment and Forestry (2016) 'Criticizing Plastic Bag Handling Policies in Indonesia', Policy Brief, 10.

Krisyanti, VOS, I. and Priliantini, A. (2020) 'The Influence of the \#Abiding Plastic Campaign on Environmentally Friendly Attitudes' (Survey of Instagram Followers @ GreenPeaceID)', Journal of Communication, Media and Informatics, 9, pp. 40-51.

Lusnita, N. (2019) 'Plastic Waste Reduction Program Through Paid Plastic Bag Policy in Modern Retail', 1(1), pp. 12-24.

Mayvita, PA and Zulfikar, R. (2018) 'THE LEVEL OF COGNITIVE, EFFECTIVE AND KONATIVE BANJARMASIN'S PUBLIC BASED ON DEMOGRAPHIC AND PSYCHOGRAFIC IN RESPONDING TO PROHIBITION POLICY THE USE OF PLASTIC AS SHOPPING BAGS', 19(2), pp. 19(2), pp. 637-649.

Niswa (2020) Community Knowledge, Attitudes and Behaviors Against the Application of Paid Plastic Bags in Makassar City Minimarkets in 2020, 1. Hasanuddin University.

Notoatmodjo, S. (2003) Health Education and Behavior. Jakarta.

Notoatmodjo, S. (2014) Behavioral Health Sciences. Jakarta.

Pramiati Purwaningrum (2016) 'Efforts to Reduce Plastic Waste Generation', Environmental Engineering, 8(2), pp. 141-147.

Prasanti, D. (2018) 'The Use of Communication Media for Adolescent Girls in Searching for Health Information, LONTAR: Journal of Communication Studies, 6(1), pp. 13-21. doi:10.30656/lontar.v6i1.645. 
E-ISSN: 2808-5361 http://e-journal.fkmumj.ac.id/
Proceeding The First Muhammadiyah InternasionalPublic Health and Medicine Conference

Purwaningrum, P. (2018) 'Efforts to Reduce the Generation of Plastic Waste in the Environment, 8, pp. 141-147.

Rahmayani, CA and Aminah (2021) 'Effectiveness of Plastic Waste Control to Support Environmental Sustainability in Semarang City', 3, pp. 18-33.

Riyanto, A. (2013) Knowledge and Attitude in Health Research. Jakarta.

Sharma, HD, and Reddy, KR (2004) 'Geoenvironmental Engineering: Site Remediation, Waste Containment, and Emerging Waste Management Technologies. Wiley, New York.'

Utami, NR et al. (2020) 'Awareness of the Use of Disposable Plastics by Biology Education Students at Tidar University, Journal of Biology Education, 1, pp. 8-12.

Victor (2012) 'History and development of Plastics'.

Yanti, N. (2011) Description of the Behavior of Housewives Using Plastic Containers for Food and Beverage Storage in East Sidorame Village, Medan Perjuangan District, 2011. North Sumatra. 